УДК 613.8+37.04:37.06

Грись Антоніна Михайлівна, доктор психологічних наук, професор, професор кафедри психології ПрАТ «ВНЗ «МАУП», 02000, вул. Фрометівська, 2, м. Київ, Україна; +38 (067) 971-73-20

ORCID: https//orcid.org/0000-0002-0153-2303

Марушевська Вікторія Воолодимирівна, магістр психології, ПрАТ ВНЗ «МАУП», 02000, вул. Фрометівська, 2, м. Київ, Україна; +38 (095) 41=14-206

ORCID:

\title{
ПРОЯВИ АДАПТАЦІЇ ДІТЕЙ МОЛОДШОГО ШКІЛЬНОГО ВІКУ
}

\begin{abstract}
Анотація
Ключові слова: шкільна адаптація, діти, початкова школа, першокласники, адаптація, дезадаптація.

Постановка проблеми. Проблема адаптації дитини до школи має комплексний (медичний, педагогічний, психологічний) характер. Дошкільний та молодший шкільний вік $\epsilon$ сензитивними періодами соціального становлення особистості дитини як повноцінного члена суспільства. Від адаптації дитини в початковій школі залежить все іiі подальше життя, тому важливо визначити основні прояви адаптації дітей до школи саме в першому класі.

Аналіз останніх досліджень і публікацій. Молодші школярі повинні, 3 одного боку, пережити зміну розпорядку дня, пристосуватися до нових умов спілкування, а з іншого - сприйняти та привнести у власне життя нові специфічні правила, вимоги і предмети, пов'язані з навчанням у школі. При порушенні успішної адаптації до умов школи, в дитини може виникнути стан дезадаптації, як результат різкої зміни умов середовища, до якого вона може бути не готова. Ознаками дезадаптації $\epsilon$ підвищена стомлюваність, дратівливість, спалахи гніву, замкнутість, погана успішність, агресивність
\end{abstract}


або, навпаки, надмірна соромливість, підвищена тривожність, низька самооцінка. Прояви дезадаптації такі: відставання від програми; швидка втомлюваність; недисциплінованість; невміння будувати відносини 3 однолітками та дорослими; підвищена тривожність, плаксивість; спад працездатності наприкінці дня; неадекватна поведінка; неуспішність у навчанні.

Формулювання мети статті. Метою $є$ теоретичне та емпіричне дослідження особливостей шкільної адаптації першокласників.

Виклад основного матеріалу. В процесі емпіричного дослідження особливостей адаптації до школи дітей молодшого шкільного віку, було проведено оцінювання рівня шкільної мотивації й адаптації за анкетою Н. Лусканової, застосовано опитувальник для визначення рівня адаптації дитини до школи (Л. М. Ковальова, Н. Н. Тарасенко), використано методику «Будиночки» О.А. Орехової, методику «Школа звірів». У 15 \% досліджених дітей виявлено негативні асоціації, пов’язані зі школою.

Висновки та перспективи подальших досліджень. Успішна адаптація до початкової школи $є$ необхідною умовою розвитку кожної дитини як особистості, їі індивідуальності, продуктивної активної діяльності, творчості.

\section{Аннотация}

Грысь А. М., доктор психологических наук, профессор, професор кафедры психологии ПрАТ «ВНЗ «МАУП»; Марушевская В. В., магистр кафедры психологии ПрАТ «ВНЗ «МАУП»; г. Киев, Украина. Проявления адаптации детей младшего школьного возраста.

Ключевые слова: школьная адаптация, дети, начальная школа, первоклассники, адаптация, дезадаптация.

Постановка проблемы. Проблема адаптации ребенка к школе имеет комплексный (медицинский, педагогический, психологический) характер. Дошкольный и младший школьный возраст являются сензитивными 
периодами социального становления личности ребенка как полноценного члена общества. От адаптации ребенка в школе зависит все его дальнейшая жизнь, поэтому важно определить основные проявления адаптации детей к школе именно в первом классе.

Анализ последних исследований и публикаций. Младшие школьники должны, с одной стороны, пережить смену распорядка дня, приспособиться к новым условиям общения, а с другой - принять и привнести в свою жизнь новые специфические правила, требования и предметы, связанные с обучением в школе. При нарушении успешной адаптации к условиям школы, у ребенка может возникнуть состояние дезадаптации, как результат резкого изменения условий среды, к которому он может оказаться не готов. Признаками дезадаптации являются: повышенная утомляемость, раздражительность, вспышки гнева, замкнутость, плохая успеваемость, агрессивность или, наоборот, чрезмерная застенчивость, повышенная тревожность, низкая самооценка. Проявления дезадаптации такие: отставание от программы; быстрая утомляемость; недисциплинированность; неумение строить отношения со сверстниками и взрослыми; повышенная тревожность, плаксивость; спад работоспособности в конце дня; неадекватное поведение; неуспеваемость в учебе.

Формулировка цели статьи. Целью является теоретическое и эмпирическое исследование особенностей школьной адаптации первоклассников.

Изложение основного материала. В процессе эмпирического исследования особенностей адаптации к школе детей младшего школьного возраста, было проведено оценивание уровня школьной мотивации и адаптации по анкете Н. Лускановой, применен опросник для определения уровня адаптации ребенка к школе (Л. Н. Ковалева, Н. Н. Тарасенко), использованы методика «Домики» А.А. Орехова и методика «Школа зверей». У 15\% исследованных детей выявлены негативные ассоциации, связанные со школой. 
Выводы и перспективы дальнейших исследований. Успешная адаптация к начальной школе является необходимым условием развития каждого ребенка как личности, его индивидуальности, продуктивной активной деятельности, творчества.

\section{Annotation}

Grys A. M., PhD, Doctor of Psychology, Professor, Professor of the of the Department of Psychology of the Private Joint-Stock Company "Higher Educational Institution "Interregional Academy of Personnel Management"; Marushevs'ka V.V., Magister of the Department of Psychology of the Private Joint-Stock Company "Higher Educational Institution "Interregional Academy of Personnel Management"; Kyiv, Ukraine._Manifestations of adaptation of children of primary school age.

Key words: school adaptation, children, elementary school, first-graders, adaptation, disadaptation.

Formulation of the problem. The problem of adapting a child to school is complex (medical, pedagogical, psychological). Preschool and primary school age are sensitive periods of the social formation of the child's personality as a fullfledged member of society. All future life depends on the child's adaptation at school, therefore it is important to determine the main manifestations of children's adaptation to school in the first grade.

Analysis of recent research and publications. Younger students should, on the one hand, survive the change of daily routine, adapt to the new conditions of communication, and on the other hand, accept and introduce into their lives new specific rules, requirements and subjects related to schooling. In case of violation of successful adaptation to school conditions, the child may experience a state of disadaptation, as a result of a drastic change in environmental conditions for which he may not be ready. Symptoms of maladaptation are: fatigue, irritability, outbursts of anger, isolation, poor performance, aggressiveness or, conversely, excessive shyness, increased anxiety, low self-esteem. Manifestations of maladjustment are: 
lag from the program; fast fatiguability; indiscipline; inability to build relationships with peers and adults; increased anxiety, tearfulness; a decline in performance at the end of the day; inappropriate behavior; academic failure.

Formulating the purpose of the article. The goal is a theoretical and empirical study of the features of school adaptation of first-graders.

The presentation of the main material. In the process of empirical research on the characteristics of adaptation to school children of primary school age, an assessment was made of the level of school motivation and adaptation on the N. Luskanova questionnaire, a questionnaire was used to determine the level of adaptation of a child to school (L. N. Kovaleva, N. N. Tarasenko), used methods "Houses" A.A. Orekhov and the School of Beasts methodology. 15\% of the children studied had negative associations associated with school.

Conclusions and prospects for further research. Successful adaptation to primary school is a prerequisite for the development of each child as an individual, his individuality, productive activity, and creativity.

Ключові слова: шкільна адаптація, діти, початкова школа, першокласники, адаптація, дезадаптація.

Актуальність дослідження. Від адаптації дитини в початковій школі залежить все ії подальше життя: якщо не прищепити любов до навчальної діяльності, якщо не створити ситуацію успіху, не розвинути якості іiі особистості, якщо дитина не навчитися дружити і спілкуватися, вона втратить інтерес до навчання. Вирішити цю проблему в середньому або старшому віці набагато важче, тому важливо визначити основні прояви адаптації дітей до школи саме в першому класі.

Постановка проблеми. Труднощі, пов'язані 3 адаптацією першокласників, є відображенням поступового входження дитини в нову соціальну ситуацію розвитку: в неї з'являються нові обов'язки (вчасно приходити до школи, виконувати домашні завдання, дотримуватися 
розкладу занять). Йде процес адаптації до нового колективу ровесників, зав’язуються ділові особисті стосунки з учителем. Нарешті, змінюється соціальна позиція дитини в сім’ї, ставлення до неї інших членів родини. Формується світогляд дитини, виникають нові уявлення і погляди. Збагачується світ іï почуттів, естетичних переживань, ширшими стають інтереси, захоплення. Всю цю «програму» дитина засвоює в перші шкільні роки. Враховуючи, що енергія дитинства практично невичерпна, якщо іiі вміло спрямувати, потрібно усвідомити, як важливо знати особливості процесу адаптації до школи кожної окремо взятої дитини, щоб запобігти різним ускладненням до завершення нею початкової ланки освіти.

Слід врахувати, що, крім інтелектуального навантаження, яке різко збільшується зі вступом дитини до школи, сильно зростають, в порівнянні 3 минулим періодом життя, й фізичні навантаження, пов’язані 3 тривалою вимушеною нерухомістю, а для дітей 6-7 років саме це являється найбільш стомлюючим.

Загалом, проблема адаптації дитини до школи має медичний, педагогічний та психологічний характер. У психології дану проблему досліджували такі вчені, як П. Блонський, Л. Божович, Я. Коломинський, Є. Панько, А. Маркова, Р. Овчарова, А. Реан, І. Дубровіна, М. Бітянова та багато інших.

Аналіз соціально-педагогічних досліджень свідчить про зростаючий інтерес учених до проблеми ранньої соціалізації дітей. Так, проблема соціалізації особистості розглядалася 3 філософських, соціологічних, психологічних, культурологічних, педагогічних позицій.

О. Кривчикова і Т. Лясота на основі аналізу літературних джерел переконують, що результативність адаптації дитини до шкільного навчання в значній мірі визначає увесь подальший період перебування в ЗОШ [5, с.162163].

Дошкільний та молодший шкільний вік $є$ сензитивними періодами соціального становлення особистості дитини як повноцінного члена 
суспільства. Значно розширюється сфера соціальних контактів дитини. На думку М.Р. Битянової, М.М. Врублевської та інших дослідників, саме в початковій школі починають формуватися системи відносин дитини зі світом і самою собою, ті стійкі форми взаємин з однолітками й дорослими та базові навчальні установки, які істотною мірою визначають надалі успішність іiі шкільного навчання, можливості особистісної самореалізації в шкільному середовищі [6, с.252].

Аналіз останніх досліджень і публікацій. Адаптація (3 латинської adapto) означає пристосування. Молодші школярі повинні, з одного боку, пережити зміну розпорядку дня, пристосуватися до нових умов спілкування, а з іншого - сприйняти та привнести у власне життя нові специфічні правила, вимоги і предмети, пов'язані з навчанням у школі.

Під адаптацією дітей до школи В. Цилєв розуміє процес звикання дитини до шкільних вимог і порядків, нового для неї оточення, умов діяльності [10, с. 27].

А. Л. Вернер виділяє такі рівні шкільної адаптації [7, с.12-13]:

- Високий: учень позитивно ставиться до школи; вимоги сприймає адекватно; навчальний матеріал засвоює легко, глибоко, повністю; розв'язує ускладнені задачі; старанний, уважно слухає вказівки, роз'яснення вчителя; виконує доручення без зайвого контролю; виявляє великий інтерес до самостійної роботи; готується до всіх уроків; має у класі позитивний статус.

- Середній: учень позитивно ставиться до школи, іiі відвідування не викликає негативних переживань; розуміє навчальний матеріал, якщо вчитель викладає його детально і наочно; засвоює головний зміст навчальних програм; самостійно розв'язує типові задачі; буває зосередженим тільки тоді, коли зайнятий чимось для нього цікавим; громадські доручення виконує сумлінно; товаришує з багатьма однокласниками.

- Низький: учень негативно ставиться до школи; бувають скарги на погане самопочуття; домінує пригнічений настрій; спостерігається порушення дисципліни; матеріал, який пояснює вчитель, засвоює 
фрагментарно, самостійна робота 3 підручником ускладнена; зберігає працездатність і увагу за умови тривалих пауз для відпочинку; близьких друзів немає.

Процес адаптації першокласників протікає на наступних рівнях:

- біологічному (пристосування до нового режиму навчання й життя);

- психологічному (входження до нової системи вимог, пов'язаних 3 виконанням навчальної діяльності );

- соціальному (входження до учнівського колективу).

Все це означає суттєву перебудову життя, фізіологічних та психічних станів першокласників, що супроводжується неприємними відчуттями дискомфорту (пов'язаними, в основному, зі втратою звичних й улюблених занять, зміною соціального оточення), зламом і дисбалансом динамічних стереотипів, швидким накопиченням нової інформації та особистісними змінами. Проявами таких станів можуть бути тривожність, фрустрація, депресія, нестача впевненості в собі, невротичні прояви [9, с. 168-171].

Адаптацію можна розглядати в різних аспектах. Але хотілося б зупинитися на основних ознаках адаптації дитини:

- перебування в спокійному, врівноваженому стані;

- стриманість, уважність на уроках; активність і рухливість на перервах; прояв інтересу до нових людей, дорослих, дітей; зацікавленість в огляді інтер'єру класу, школи, приміщень; спостережливість, інтерес до старшокласників;

- легка орієнтація у просторі школи, демонстрація батькам своєї обізнаності вже через тиждень;

- легке розуміння і готовність виконувати вимоги вчителя, не чекаючи його заохочення; позитивне оцінювання дитиною своїх дій, результатів власних зусиль;

- адекватне сприйняття негативної оцінки дорослого;

- ініціативний характер спілкування в період навчальної діяльності; активність на уроках; 
- комунікабельність у спілкуванні 3 учнями не лише свого класу; успішне опанування навчального матеріалу [4, с. 275].

При порушенні успішної адаптації до умов шкільного середовища, в дитини може виникнути стан дезадаптації, що $є$ негативним наслідком спотворення процесу активного пристосування учня першого класу до нових умов. Дезадаптація може настати як результат різкої зміни умов середовища, до якого дитина може бути не готова [3, с. 53].

Ознаками дезадаптації є: підвищена стомлюваність, дратівливість, спалахи гніву, замкнутість, погана успішність, агресивність або, навпаки, надмірна соромливість, підвищена тривожність, низька самооцінка. Прояви дезадаптації такі: відставання від програми; швидка втомлюваність; недисциплінованість; невміння будувати відносини 3 однолітками та дорослими; підвищена тривожність, плаксивість; спад працездатності наприкінці дня; неадекватна поведінка; неуспішність у навчанні [8, с.41].

Сучасні науковці виділяють низку причин, що визначають прояви дезадаптації учнів першого класу [1, с. 12]:

- неправильні методи виховання в сім’ї: завищені очікування батьків щодо навчання дітей; байдуже ставлення до навчання та виховання дитини; акцентування уваги дитини на недоліках школи чи педагога замість розмов про приємні моменти шкільного життя; гіперопіка дитини;

- порушення відносин у школі в системі «учень - вчитель», «учень учні»: дидактогенія (психогенний вплив чинить сам процес навчання); дидаскалогенія (некоректне ставлення вчителя до учня); злиття дидактогенії й індивідуальної чутливості центральної нервової системи дитини; порушення стосунків з однокласниками;

- індивідуальні особливості психічного розвитку дитини: невисокий інтелектуальний потенціал; затримка психічного розвитку; гіперактивність; труднощі у вольовій регуляції поведінки, навчальної діяльності; несформованість мотивації до навчання; завищена самооцінка й рівень домагань дитини чи батьків; підвищена чутливість ЦНС; підвищений рівень 
тривожності; агресивність; замкнутість; соматичне ослаблення (хронічні захворювання) тощо [2, с. 14].

Формулювання мети статті. Метою $є$ теоретичне та емпіричне дослідження особливостей шкільної адаптації першокласників.

Виклад основного матеріалу. На першому етапі емпіричного дослідження особливостей адаптації до школи дітей молодшого шкільного віку, було проведено оцінювання рівня шкільної мотивації й адаптації за анкетою Н. Лусканової. За цією методикою отримали такі результати: середній і низький рівень шкільної адаптації співпадають і становлять по 30\% у першокласників, високий рівень шкільної адаптації у 12 \% досліджених дітей, зовнішня мотивація у $20 \%, 8$ \% - шкільна дезадаптація. Діти з високим рівнем адаптації відносно швидко входять в колектив, освоюються в школі, знаходять нових друзів в класі, у них майже завжди гарний настрій, вони доброзичливі, сумлінно i без видимої напруги виконують всі вимоги вчителя. Іноді в них відмічаються складності або в контактах з дітьми, або у стосунках із учителем, оскільки їм ще важко виконувати всі вимоги правил шкільної поведінки, але до кінця жовтня відбувається засвоєння і нового статусу, i нових вимог, i нового режиму. Ці якості дозволяють $і$ ім із перших днів відчути свої успіхи, що ще більше підвищує навчальну мотивацію. Це легка форма адаптації. Діти 3 середнім рівнем адаптації мають тривалий період адаптації, період невідповідності їхньої поведінки вимогам школи затягується: діти не можуть прийняти ситуацію навчання, спілкування 3 учителем, дітьми. Як правило, ці діти зазнають труднощі в засвоєнні навчальної програми. Завдяки доброзичливому i тактовному відношенню вчителя, до кінця першого півріччя реакції цих дітей стають адекватними шкільним вимогам. Це форма середнього рівня адаптації.

Зовнішня мотивація буває різною - від кишенькових грошей до оцінок в школі. Вона зводиться до фрази: «Зроби ось так - і отримаєш ось це». Психолог Альфі Кон в книзі «Покарання нагородою» застерігає не тільки 
батьків, але і вчителів від різних заохочень. Одні батьки обіцяють зводити дитину в зоопарк за гарне навчання, інші купують гаджети або навіть платять гроші. Проблема в тому, що це не працює: школяр вчиться так само погано, а на додачу ще й ображається, що не отримав те, що йому обіцяли.

Діти, в яких соціально-психологічна адаптація пов'язана із значними труднощами, погано засвоюють навчальну програму, у них проявляються негативні форми поведінки, різкий прояв негативних емоцій. Саме на таких дітей найчастіше скаржаться вчителі, батьки. Постійні неуспіхи в навчанні, відсутність контакту 3 вчителем створюють відчуження i негативне відношення однолітків. Серед цих дітей можуть бути ті, хто потребує лікування - у учні 3 порушеннями психоневрологічної сфери, проте можуть бути і учні, не готові до навчання в школі. Це «група ризику».

На другому етапі дослідження, було застосовано опитувальник для визначення рівня адаптації дитини до школи (Л. М. Ковальова, Н. Н. Тарасенко). Майже у половини досліджуваних першокласників дезадаптація відсутня, нормальний показник. У 28 \% дітей середній показник дезадаптації, у $17 \%$ дітей високий показник дезадаптації, у 7 \% - серьозний показник дезадаптації. Отже, 52 \% всіх опитаних першокласників потребують допомоги з боку вчителів та батьків. Тобто більшість дітей відчувають труднощі у навчанні, у спілкуванні з учителями та однолітками.

На третьому етапі була використана методика «Будиночки» О. А. Орєхової. Отримали такі результати за завданням № 1 цієї методики: 48 \% першокласників навчаються у оптимальному для них режимі. У $12 \%$ спостерігається хронічна втома, у 13 \% є перезбудження, у 27 \% стан втоми компенсується, тобто самовідновлення оптимальної працездатності відбувається за рахунок періодичного зниження активності.

Далі були отримані дані за методикою «Будиночки» по завданню № 2 для кожного учня. Завдання № 2 характеризує сферу соціальних емоцій. У 40 \% дітей емоційний стан в нормі, у 23 \% першокласників переважають позитивні емоції, у 37 \% - переважають негативні емоції. 
У завданні №3 відображено емоційне ставлення дитини до себе, шкільної діяльності, вчителя та однокласників. Позитивне ставлення до школи маємо у 43 \% всіх досліджуваних дітей. У 27 \% учнів спостерігається негативне відношення до школи, у 30 \% - амбівалентне відношення.

Наступна методика, що була застосована у дослідженні, методика «Школа звірів». У 17 дітей з усіх досліджуваних відсутні негативні асоціації, пов'язані зі школою. У 6-ох першокласників наявні негативні асоціації зі школою, у 9 - ти дітей присутня внутрішня агресія, у 8 - ми учнів наявні труднощі у спілкуванні 3 однолітками. На рисунку 1 можна побачити структурний розподіл результатів дослідження за методикою «Школа звірів».

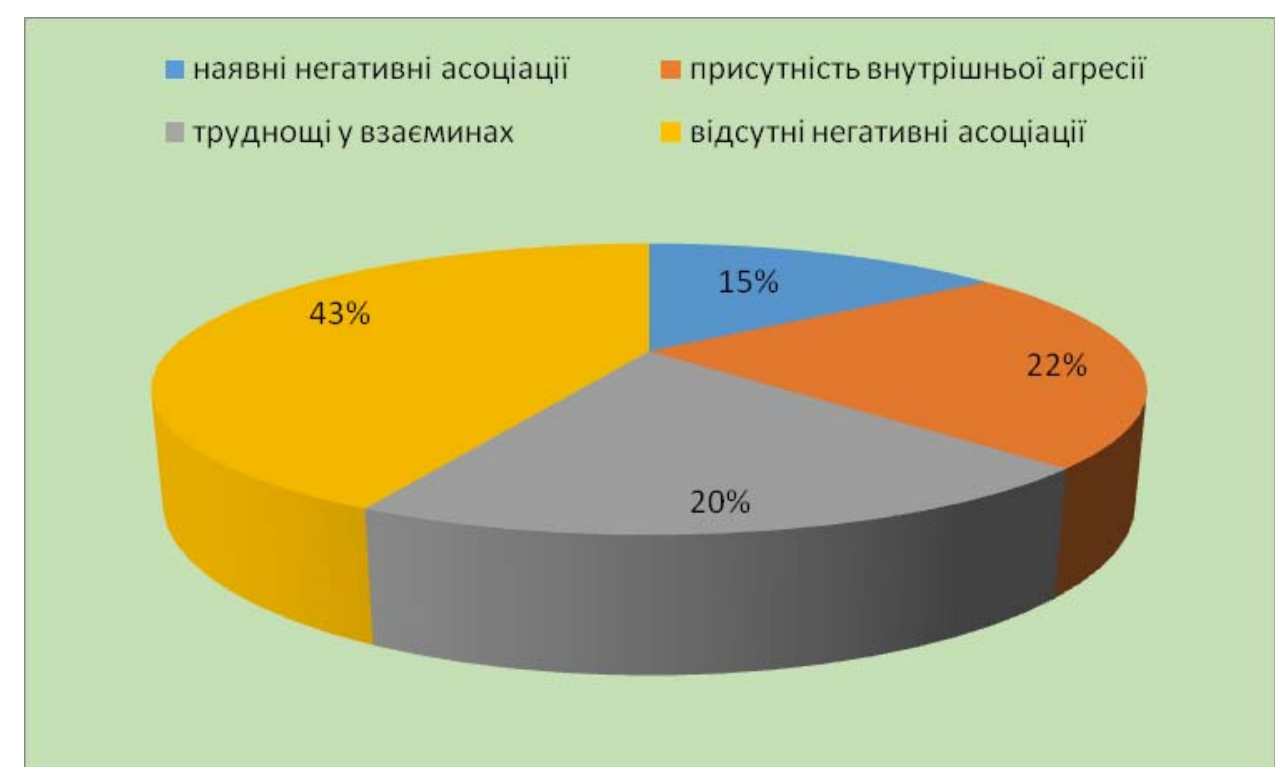

Рис. 1 Структурний розподіл результатів за проективною методикою «школа звірів»

У 43 \% випробовуваних школярів відсутні негативні асоціації, у 22 \% дітей присутня внутрішня агресія. Труднощі у взаєминах спостерігаються у $20 \%$ досліджуваних першокласників. У $15 \%$ дітей наявні негативні асоціації, що пов'язані зі школою.

Висновки та перспективи подальших досліджень. Процес адаптації до шкільного навчання може викликати у дитини серйозне психічне навантаження, тому що вступ до першого класу означає суттєву перебудову життя, фізіологічних та психічних станів першокласників, що 
супроводжується неприємними відчуттями дискомфорту, швидким накопиченням нової інформації та особистісними змінами.

Основні ознаки успішної адаптації дитини такі: перебування в спокійному, врівноваженому стані; стриманість, уважність на уроках; активність і рухливість на перервах; прояв інтересу до нових людей, дорослих, дітей; зацікавленість в огляді інтер’єру класу, школи, приміщень; спостережливість, інтерес до старшокласників; легка орієнтація у просторі школи, демонстрація батькам своєї обізнаності вже через тиждень; легке розуміння i готовність виконувати вимоги вчителя, не чекаючи його заохочення; позитивне оцінювання дитиною своїх дій, результатів власних зусиль; адекватне сприйняття негативної оцінки дорослого; ініціативний характер спілкування в період навчальної діяльності; активність на уроках; комунікабельність у спілкуванні з учнями не лише свого класу; успішне опанування навчального матеріалу.

Підсумовуючи результати проведеного емпіричного дослідження, можна зробити висновки, що слід приділити увагу емоційному стану першокласників, налагодити взаємини між учнями, допомогти дітям організувати оптимальний навчальний режим.

Успішна адаптація до початкової школи $\epsilon$ необхідною умовою розвитку кожної дитини як особистості, іiі індивідуальності, продуктивної активної діяльності, творчості.

\section{Список використаних джерел}

1. Берник О. Н., Козак I. К.: Адаптаційні заняття для майбутніх першокласників, які не відвідують ДНЗ / О. Н. Берник, І. К. Козак // Почат. навчання та виховання: наук.-метод. журн. - 2009. - № 27. - С. 3-14.

2. Гуріна О. Адаптація першокласників: Семінар для вчителів початкових класів / О. Гуріна // Психолог. Шкільний світ. - 2008. - № 15. - С. 13-16.

3. Дубчак О. Дитина йде до школи: радощі й турботи / О. Дубчак // Початкова школа. - 2003. - № 4. - С. 52-55. 
4. Лемешева Т. Є. Етапи соціалізації дитини: підготовка до школи та адаптація першокласників / Т. Є. Лемешева, І. М. Подавільнікова // Таврійський вісник освіти. - 2013. - N 4. - С. 270-278.

5. Кривчикова О. Психомоторний стан як фактор адаптації учнів початкових класів до умов навчання в школі / О. Кривчикова, Т. Лясота // Фізичне виховання, спорт і культура здоров'я у сучасному суспільстві.2008.- №2.- С. 162-164.

6. Крупник Г. А. Особливості психологічного супроводу адаптації першокласників до навчального процесу / Крупник Г. А. // Таврійський вісник освіти.- 2014.- № 2 (46).- С. 251-257.

7. Опанасюк Г. Алгоритм супроводу дітей в адаптаційний період / Г. Опанасюк // Психолог.- 2009.- Січень (№3-4).- С. 12-18.

8. Перегончук Н. Психологічні основи проявів дезадаптації учнів початкової школи / Н. Перегончук // Наукові записки: Збірник матеріалів науково-практичної конференції викладачів і студентів.- Серія «Початкове навчання».- Вип. 5. Частина II.- Вінниця, 2007.- С. 40-42.

9. Розіна І. В. Вплив тривожності на процес адаптації учнів п’ятих класів / I. В. Розіна, Х. О. Андріяш // Вісник Чернігівського національного педагогічного університету імені Т.Г.Шевченка.-2010.- Т II.-№ 82.-С.168-171.

10. Цилєв В. Діагностика психологічної готовності дітей до школи / В. Цилєв // Все про адаптацію.- 2004.- №25-26.- С. 14-21.

\section{References}

1. Bernyk, O. N. Kozak, I. K. (2009), Adaptatsiini zaniattia dlia maibutnikh pershoklasnykiv, yaki ne vidviduiut DNZ, [Adaptation classes for future firstgraders who do not attend the DNE], Pochat. navchannia ta vykhovannia: nauk.metod. Zhurn., vol.27, pp. 3-14.

2. Hurina, O. (2008), Adaptatsiia pershoklasnykiv: Seminar dlia vchyteliv pochatkovykh klasiv, [Adaptation of first-graders: Seminar for primary school teachers], Psykholoh. Shkilnyi svit, vol. 5, pp. 13-16. 
3. Dubchak, O. (2003), Dytyna yde do shkoly: radoshchi y turboty, [The child goes to school: joys and cares ], Pochatkova shkola/ vol. 4, pp. 52-55.

4. Lemesheva, T. E. Podadlivnikova, I. M. (2013), Etapy sotsializatsii dytyny: pidhotovka do shkoly ta adaptatsiia pershoklasnykiv, [Stages of socialization of a child: preparation for school and adaptation of first-graders], Tavriiskyi visnyk osvity, vol. 4, pp. 270-278.

5. Kryvchykova, O. Liasota, T. (2008), Psykhomotornyi stan yak faktor adaptatsii uchniv pochatkovykh klasiv do umov navchannia $v$ shkoli, [Psychomotor state as a factor of adaptation of primary school pupils to school conditions], Fizychne vykhovannia, sport i kultura zdorovia u suchasnomu suspilstvi, vol. 2, pp. 162-164.

6. Krupnyk, H. A. (2014), Osoblyvosti psykholohichnoho suprovodu adaptatsii pershoklasnykiv do navchalnoho protsesu, [Features of psychological support of adaptation of first-graders to the educational process ], Tavriiskyi visnyk osvity, vol. 2 (46), pp. 251-257.

7. Opanasiuk, H. (2009), Alhorytm suprovodu ditei v adaptatsiinyi period, [The Algorithm for Accompanying Children in the Adaptation Period], Psykholoh, vol. 1(3-4), pp. 12-18.

8. Perehonchuk, N. (2007), Psykholohichni osnovy proiaviv dezadaptatsii uchniv pochatkovoi shkoly, [Psychological bases of manifestations of maladaptation of elementary school students], Naukovi zapysky: Zbirnyk materialiv naukovo-praktychnoi konferentsii vykladachiv i studentiv. Seriia «Pochatkove navchannia», vol. 5, Ch. II, pp. 40-42.

9. Rozina, I. V. (2010), Vplyv tryvozhnosti na protses adaptatsii uchniv piatykh klasiv, [Influence of anxiety on the process of adaptation of fifth grade students], Visnyk Chernihivskoho natsionalnoho pedahohichnoho universytetu imeni T. H. Shevchenka, T II, vol. 82, pp.168-171.

10. Tsyliev, V. (2004), Diahnostyka psykholohichnoi hotovnosti ditei do shkoly, [Diagnostics of children's psychological readiness for school], Vse pro adaptatsiiu, vol. 25-26, pp. 14-21. 